\title{
MODELS OF TRAINING PROCEDURES
}

Khodakov V. Ye. - Dr. Sc., Professor, Head of the Department of Information Technologies, Kherson National Technical University, Kherson, Ukraine.

Sokolov A. Ye. - PhD, Associate Professor, Associate Professor of the Department of Information Technologies, Kherson National Technical University, Kherson, Ukraine.

Veselovskaya G. V. - PhD, Associate Professor, Associate Professor of the Department of Information Technologies, Kherson National Technical University, Kherson, Ukraine.

\section{ABSTRACT}

Context. The problem of justifying methods for constructing models of optimization procedures as dynamic objects, taking into account the features of the training procedures, is considered. The object of the study were models of the dynamics of training procedures.

Objective. The goal of the work is to solve the tasks of formalizing the training procedures, developing methods for constructing mathematical models of the learning processes, the processes of searching for the optimum of the learning tasks, and for evaluating dynamic training procedures.

Method. The learning process is a totality of sequential and interrelated actions of a teacher and learners, aimed at providing a conscious and durable assimilation of knowledge, abilities, and skills. As a result of systematic analysis, main, basic patterns of training procedures are defined. The notion of "information flow" is justified as the sequence of messages carrying information for building models of interactions in information systems. The important property of the information flow is determined - the direction from the source to the receiver. Two possible variants of information interaction of objects are singled out - information transfer and information compensation. The use of optimality principle for information processes of learning is offered. It is shown that the dynamics of learning processes is determined by the characteristics of the used optimization procedure. The gradient procedure for finding the extremum of the goal function is described by the autonomous motion of the dynamic system. For a strictly convex goal function, according to sufficient optimality conditions, the optimization procedure is described by the dynamics of the autonomous motion of a stationary linear unbound dynamic object. The choice of the multiplier for the gradient significantly affects the dynamics of the process, and for a strictly convex goal function the multiplier is equal to the increment vector. The use of a dynamic model determines the number of steps required to achieve the given accuracy.

Results. The created models received software implementation and were investigated in practice when solving the tasks of modeling the dynamics of training procedures in the teaching process of the Information Technologies Department of Kherson National Technical University.

Conclusions. The carried out experimental researches have allowed to confirm practically operability of the created mathematical apparatus and to consider it expedient for application with the purpose of increase of efficiency of modeling and realization of training procedures. Further perspectives of the research are seen in the coverage of more types of dynamic training procedures, optimizing approaches to their software implementations, and increasing the scale of their coverage with confirmatory experiments.

KEYWORDS: training, formalization of training procedures, teacher, student, information flow, optimization procedures.

\author{
ABBREVIATIONS \\ GDP is a gross domestic product; \\ IT are information technologies; \\ KhNTU is Kherson National Technical University.
}

\section{NOMENCLATURE}

$A$ is a matrix of the partial differentials $\partial f_{i} / \partial y_{i} \mid y^{*}$;

$B$ is a control matrix that leads to correction of the optimization procedure;

$C$ is some object of the information interaction;

$D$ is another object of the information interaction;

$d W$ is a differential for the resulting learning effectiveness; $f()$;

$d \boldsymbol{x}$ is a differential for the variable $\boldsymbol{x}$ of the function $f()$;

$d y$ is a differential for the variable $y$ of the function

$d \varepsilon$ is a differential for the costs of training;

$f()$ is an integrated function associated with the dynamic learning procedure;

$f^{*}$ is a specified value of the goal function;

$f_{0}$ is an initial value of the goal function;

$\operatorname{grad} f()$ is a gradient calculation function associated with the function $f()$;
$I_{C}$ is an information flow of the object $C$;

$I_{D}$ is an information flow of the object $D$;

$I_{E}$ is a difference of the information flows;

$\ln$ is a mathematical calculation of the natural logarithm;

min is an operation for determining the minimum of the goal function;

$R$ is a remainder of the power series representing the function $f()$;

$t_{m}$ is a time for finding the optimal solution for the number of steps $m$;

$u$ is a control leading to correction of the optimization procedure;

$W$ is a resulting effectiveness of training;

$W_{0}$ is a initial learning effectiveness;

$x$ is an integrated input variable of function $f()$;

$y$ is an integrated output variable of function $f()$;

$y^{*}$ is the specified value of the variable $\mathbf{y}$ of the function $f()$;

$y_{n}$ is a $n$-th unordered value of the variable $y^{*}$;

$y_{n+1}$ is a $(n+1)$-th increment value of the variable $y^{*}$.

$\partial f / \partial y \mid y^{*}$ is a partial differential of the function $f()$ with respect to the variable $y$ at the local point $y^{*}$; 
$\partial f_{i} / \partial y_{i} \mid y^{*}$ is a partial differential of the $i$-th local function $f_{i}()$ on the $i$-th variable $\boldsymbol{y}_{i}$ at the local point $\boldsymbol{y}^{*}$;

$\Delta \boldsymbol{x}$ is an increment of the variable $\boldsymbol{x}$ of the function $f()$;

$\Delta y$ is an increment of the variable $y$ of the function $f()$;

$\Delta \varepsilon$ is an increment of training costs;

$\alpha$ is an integrated speed for the dynamic training procedure;

$\alpha_{i}$ is a local speed associated with the $f_{i}()$ function of the dynamic training procedure;

$\varepsilon$ is a training costs;

$\eta$ is a sensitivity of the effectiveness of education to the costs of it;

$\lambda$ is a specified accuracy of determining the minimum value of the target function;

$\chi$ is an other costs.

\section{INTRODUCTION}

Knowledge is the basis of modern technologies including teaching ones.

Preservation and accumulation of knowledge is an indispensable element of the development of society.

A reliable way to save and gain knowledge is the learning process.

Training is a kind of educational activity in which the quantity and quality of the elements of knowledge and skills of a trainee are brought to the proper level (average, standard, possible) by a teacher that makes up the learning goal.

The activity of training is considered complete, and its goal is achieved if quantity and quality of the educational material in the re-manufactured product of a trainee will correspond to the objectives of the training or form the proper level (average, standard, possible) presented for the training purpose.

The learning process is a set of sequential and interrelated actions of an instructor and learner aimed at providing a conscious and lasting assimilation of the system of scientific knowledge, skills, the ability to use them in life, to develop independent thinking, observation and other cognitive abilities of trainees, mastering the elements of culture and mental work as well as formation of the worldview foundations.

The object of study is a set of the models for the dynamics of the training procedures.

The subject of study is a set of the conceptual approaches and ways for modeling dynamic learning procedures.

The purpose of the work is to solve the tasks of formalizing the training procedures, developing methods for constructing mathematical models of the learning processes, the processes of searching for the optimum of the learning tasks, and for evaluating dynamic training procedures.

\section{PROBLEM STATEMENT}

Despite the existence of certain results of studies of convergence rates of search procedures of optimal [22], the question of justifying the methods for constructing models of optimization procedures as dynamic objects at the moment has not been sufficiently developed.

In accordance with the above, the main problematic issue of this work is the solution of the problems of formalization of training procedures, the development of methods for constructing mathematical models of learning processes, the processes of searching for optimal learning tasks and evaluating dynamic training procedures.

\section{REVIEW OF THE LITERATURE}

Let's start with the question of tasks and characteristics of education.

Considering education as a holistic, purposeful process it is possible to distinguish four stages of formation and implementation of the learning objectives:

a) study of objective factors and definition of the general goal of education (requirements of the society to education, the level of development of fundamental sciences, etc.);

b) embodiment of the general goal of education in curricula, textbooks, technical means of teaching, methodological aids;

c) implementation of the goals and objectives of training in the actions of teachers while training students;

d) awareness of the goals and objectives of education and self-training of the students and their conscious desire to adjust their education accordingly.

In the specific cycle of the educational process the goals and objectives of the training are determined on the basis of the requirements of the curriculum taking into account the characteristics of the given class (group), the level of its preliminary preparation, education, upbringing and development as well as considering the possibilities of a teacher, a classroom equipment, didactic teaching aids.

Teaching methods use information and communication technologies [1-3] the essence of which is to use modern high-tech means of information transfer such as computers, laptops, digital projectors, simulators. Information is presented in the form of a visual-shaped series to students, and the phenomenon or process can be detailed and presented in dynamics.

A significant difference of modern computer learning technologies is their interactivity achieved by simulating situations and feedback of a learner with the information support system of a teacher.

The principle of feedback in pedagogy and of scientific teaching methods is presented in [4-6] which emphasizes that learning is the process of transferring knowledge and skills from a teacher to a student until the student acquires the ability to independently reproduce the teacher's activity.

Negative feedback is emphasized in the training system.

Next we consider the question about characteristics of teaching technologies. 
Generalized modern teaching technologies are based on advances in information technology [7, 8].

To build models we use the concept of information flow.

As the information flow we will understand the sequence of messages carrying information.

Actually, this is the simplest definition, and in this case the information stream has only one property which is directed from the source to the receiver.

We denote the information flow by an arrow indicating the flow direction, emphasizing the flow belonging to a particular source.

With this approach we get only four possible cases for two objects $C$ and $D$, namely: $C$ - source, $D$ - receiver; $C$ - receiver, $D$ - source; $C$ - source and $D$ - source; and, in the latter case, $C$ is the receiver and $D$ is the receiver.

It is obvious that only case $C$ is a source, $D$ is a receiver where information is transmitted from source $C$ to receiver $D$, and the case when $C$ and $D$ are sources is the case of compensation or comparison of information flows when a "difference" information stream carrying information about the difference of information in streams $C$ and $D$.

To denote the operation of comparing flows we use the symbol of algebraic summation and in this case we can obtain two elements for constructing the scheme which we call the conditional model depicting interaction of information flows (Fig. 1, Fig. 2):

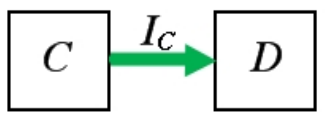

Figure 1 - The transmission of information by $I_{C}$ stream from source $C$ to receiver $D$

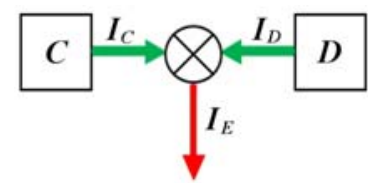

Figure 2 - Compensation of information flow $I_{C}$ by information flow $I_{D}$ and formation of information difference flow in $I_{C}$ and $I_{D}$ streams or "difference of the flows" $I_{E}$

Actually, these are two "bricks" from which the description of information flows can be constructed.

The processes in the source or the receiver can be complex but within the accepted definition of the information flow the information interaction is limited only by these two processes.

The model is important in the training system as a means of describing the outside world.

But when constructing a model the most important is the notion of an adequate model - its correspondence to an object.

The model constructed with the smallest possible error is optimal in the sense of its construction based on the implementation of the procedure for finding conditions for which a minimal estimate of the deviation in the model from the object is characteristic.
To describe the learning processes it is advisable to use the principle of optimality - the processes of information processing while training are described by optimization procedures.

Proceeding from the above we have a simple scheme of the system structure - the conditional structural model (Fig. 3).

Estimation of eviation

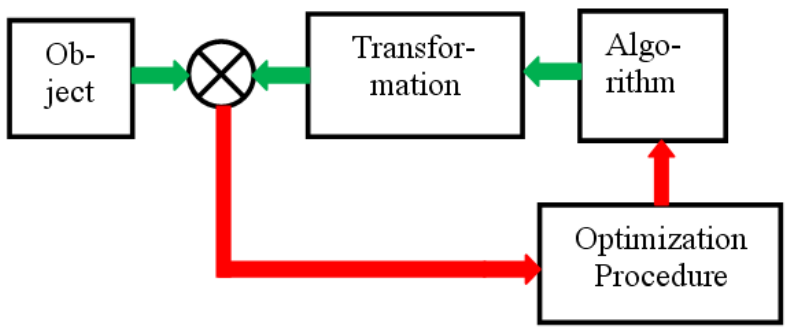

Figure 3 - Enlarged system structure

The above enlarged structure (Fig. 3) takes into account the compensation of the information flow created by the object from the information flow side in accordance with the created modelling algorithm which is determined by the procedure for minimizing the "difference" information flow.

Thus, we have the ability to represent information flows in the system.

Let's call it the structural modelling of information systems - learning systems.

For all its simplicity, the proposed method allows to obtain an algorithm for processing information in the learning system on the basis of a "structural" model.

For various objects and transformations of algorithm steps into a model compared to an object, the general requirement is the requirement of optimality to achieve a minimum deviation of the model from the object.

Transferring the principle of optimality to the training system, we can evaluate the dynamics of the training procedure.

Modern information technology is largely based on the use of optimization procedures that ensure high efficiency of their implementation [9].

At the same time the complexity and coherence of the tasks being solved causes the appearance of significant time-consuming optimization which is manifested as the effect of the dynamics in optimization procedures [10].

It should be borne in mind that with the development and improvement of information technology the task to find the best solutions takes an increasing share among all processes.

The desire to increase the productivity and accuracy of information processing processes led to a revision of the approach in determining the amount of information and the transition to the analysis and synthesis of information systems in the information space [11].

The dynamic properties of the optimization procedure are manifested with decreasing step of the procedure. 
It is obvious that with the development of information technology optimization procedures will acquire the properties of an independent dynamic object.

As a consequence it becomes necessary to build mathematical models of the dynamics for the optimization procedure.

We conclude with the question of the research purpose.

Nowadays there is the number of studies on the rate of convergence of a procedure for finding an optimum [22], but the question of justifying the methods for constructing an optimization procedure model as a dynamic object is poorly illuminated.

Thus, the goal of the study is to solve the problems of formalizing the training procedures, developing methods for constructing mathematical models of the learning processes, the processes of searching for the optimum of the learning tasks, and for evaluating dynamic training procedures.

\section{MATERIALS AND METHODS}

To construct a model for the time behavior of the gradient procedure, let us consider an autonomous stationary nonlinear dynamical object of the first order [13] by the formula (1):

$$
\frac{d y}{d x}=f(y) .
$$

We perform the linearization of the right-hand side of the equation (1). To do this we assume that the function on the right-hand side of the equation (1) can be represented by a power series [13] around point $y^{*}$ by the formula (2):

$$
f(\boldsymbol{y}, \boldsymbol{x})=f\left(\boldsymbol{y}^{*}\right)+\left.\frac{1}{1 !} \frac{\partial f}{\partial \boldsymbol{y}}\right|_{\boldsymbol{y}^{*}} \Delta \boldsymbol{y}+\ldots+R .
$$

After transferring the origin to point $y^{*}$ we obtain in (2) the first approximation of the right-hand side function in (2) by the formula (3):

$$
\left.f(y, x) \approx \frac{1}{1 !} \frac{\partial f}{\partial y}\right|_{y^{*}} \Delta y .
$$

Using the linear approximation (3), we obtain the formula (4):

$$
\left.\frac{d y}{d x} \approx \frac{\partial f}{\partial y}\right|_{y^{*}} \Delta y .
$$

Taking into account (4) and returning to increments, we have the formula (5):

$$
\frac{\boldsymbol{y}+\Delta \boldsymbol{y}-\boldsymbol{y}}{\Delta \boldsymbol{x}} \approx \frac{d f}{d \boldsymbol{y}}{\mid y^{*}} \Delta \boldsymbol{y} .
$$

Moving the origin to the point $y^{*}$ and going to increments in (5), we obtain the formula (6):

$$
y^{*}+\Delta y=y^{*}+\left.\Delta x \frac{d f}{d y}\right|_{y^{*}} \Delta y .
$$

Denoting $\boldsymbol{y}^{*}=\boldsymbol{y}_{n}$ and $\boldsymbol{y}^{*}+\Delta \boldsymbol{y}=\boldsymbol{y}_{n+1}$ in (6), we obtain the model of the Runge-Kutta method of the first order [14] by the formula (7):

$$
\boldsymbol{y}_{n+1}=\boldsymbol{y}_{n}+\frac{d f}{d \boldsymbol{y}_{\boldsymbol{y}_{n}}} \boldsymbol{y}_{n} \Delta \boldsymbol{x} .
$$

Linearization is performed at each point of the trajectory.

We have the case of transition to new variables and the product $\Delta x y_{n}=\alpha$ determines the speed of movement for the procedure.

Introducing $\alpha$ into (7), we obtain the expression (7) in the form of the formula (8):

$$
\boldsymbol{y}_{n+1}=\boldsymbol{y}_{n}+\alpha \frac{d f}{d \boldsymbol{y}_{\mid y_{n}}} .
$$

Replacing the derivative in $\operatorname{grad} f(y)$ in (8), which is true for (1), we obtain (7) as a gradient procedure [14] by the formula (9):

$$
\boldsymbol{y}_{n+1}=\boldsymbol{y}_{n}+\alpha \cdot \operatorname{gradf}{\boldsymbol{y}_{n}}_{.}
$$

Therefore, the dynamics in the free movement of an object described by the linear differential equation (1) corresponds to the motion of the gradient optimization procedure with a correction factor before the gradient $\alpha=$ $=\Delta x y_{n}$.

Similarly, as for a one-dimensional object (1) a multidimensional linear dynamic object can be represented by the formula (10):

$$
\frac{d y}{d x}=A y .
$$

Matrix $\boldsymbol{A}$ in (10) can be regarded as the matrix of a linearized object by the formula (11), consisting of the functions gradients in the right-hand side:

$$
\boldsymbol{A}=\left(\begin{array}{ccc}
\frac{\partial f_{1}}{\partial \mathbf{y}_{1}} & \cdots & \frac{\partial f_{1}}{\partial \boldsymbol{y}_{n}} \\
\cdots & \cdots & \cdots \\
\frac{\partial f_{n}}{\partial \mathbf{y}_{1}} & \cdots & \frac{\partial f_{n}}{\partial \mathbf{y}_{n}}
\end{array}\right)_{\boldsymbol{y}^{*}}=\left[\begin{array}{c}
\operatorname{grad} f_{1} \\
\vdots \\
\operatorname{grad} f_{n}
\end{array}\right]_{\boldsymbol{y}^{*}} .
$$

The Runge-Kutta method of the first order gives the procedure in the form of the formula (12):

$$
\left[\begin{array}{c}
\boldsymbol{y}_{k+1}^{1} \\
\vdots \\
\boldsymbol{y}_{k+1}^{n}
\end{array}\right]=\left[\begin{array}{c}
\boldsymbol{y}_{k}^{1} \\
\vdots \\
\boldsymbol{y}_{k}^{n}
\end{array}\right]+\left(\begin{array}{ccc}
\frac{\partial f_{1}}{\partial \boldsymbol{y}_{1}} & \cdots & \frac{\partial f_{1}}{\partial \boldsymbol{y}_{n}} \\
\cdots & \cdots & \cdots \\
\frac{\partial f_{n}}{\partial \boldsymbol{y}_{1}} & \cdots & \frac{\partial f_{n}}{\partial \boldsymbol{y}_{n}}
\end{array}\right)_{\boldsymbol{y}^{*}} \cdot\left[\begin{array}{c}
\boldsymbol{y}_{k}^{1} \\
\vdots \\
\boldsymbol{y}_{k}^{n}
\end{array}\right] \Delta \boldsymbol{x} .
$$


In the vector notation procedure (12) has the form of the formula (13):

$$
\boldsymbol{y}_{k+1}=\boldsymbol{y}_{k}+\boldsymbol{A}_{\boldsymbol{y}} * \boldsymbol{y}_{k} \Delta \boldsymbol{x}
$$

On the other hand, in the problem of finding the minimum of a target function that depends on the vector of the formula (14):

$$
\boldsymbol{y}^{*} \rightarrow \min f(\boldsymbol{y})
$$

the gradient procedure (9) takes the form of the formula (15):

$$
\boldsymbol{y}_{k+1}=\boldsymbol{y}_{k}+\alpha \cdot \operatorname{gradf} \boldsymbol{y}_{k} .
$$

In componentwise recording, the gradient procedure (15) has the form of the formula (16):

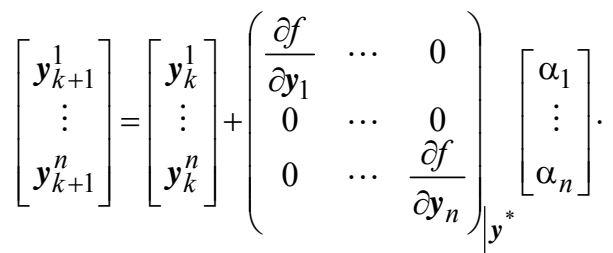

Thus, first-order Runge-Kutta procedure for system (12) differs from the gradient procedure for problem (16), first, in that matrix $\boldsymbol{A}$ for the gradient procedure is diagonal and, secondly, by the fact that the factor $\alpha$ in the gradient procedure is chosen from considerations of convergence, and in (12) the factor is defined.

Proceeding from this, it can be asserted that the model for the dynamics of the gradient procedure is the model of free motion of a disconnected linear object if the following condition in the formula (17) is true:

$$
\left[\begin{array}{c}
\alpha_{1} \\
\vdots \\
\alpha_{n}
\end{array}\right]=\left[\begin{array}{c}
y_{k}^{1} \Delta x \\
\vdots \\
y_{k}^{n} \Delta x
\end{array}\right]
$$

In the general case, taking into account (17) the model for the dynamics of the gradient procedure (16) is described by the Runge-Kutta procedure of first order, and correction of the optimization procedure is described as the control $\boldsymbol{u}$ with the matrix $\boldsymbol{B}$ by the formula (18):

$$
\boldsymbol{y}_{k+1}=\boldsymbol{y}_{k}+\boldsymbol{A}_{\boldsymbol{y}} * \boldsymbol{y}_{k} \Delta \boldsymbol{x}+\boldsymbol{B} \boldsymbol{u}_{k} \Delta \boldsymbol{x}
$$

For the identity control matrix procedure (18) takes the form of the formula (19):

$$
\left[\begin{array}{c}
\boldsymbol{y}_{k+1}^{1} \\
\vdots \\
\boldsymbol{y}_{k+1}^{n}
\end{array}\right]=\left[\begin{array}{c}
\boldsymbol{y}_{k}^{1} \\
\vdots \\
\boldsymbol{y}_{k}^{n}
\end{array}\right]+\left(\begin{array}{ccc}
\frac{\partial f}{\partial \boldsymbol{y}_{1}} & \cdots & 0 \\
\cdots & \cdots & \cdots \\
0 & \cdots & \frac{\partial f}{\partial \boldsymbol{y}_{n}}
\end{array}\right)_{\boldsymbol{y}^{*}} \cdot\left[\begin{array}{c}
\boldsymbol{y}_{k}^{1} \\
\vdots \\
\boldsymbol{y}_{k}^{n}
\end{array}\right] \Delta \boldsymbol{x}+\left(\begin{array}{ccc}
1 & \cdots & 0 \\
\cdots & \cdots & \cdots \\
0 & \cdots & 1
\end{array}\right)_{\boldsymbol{y}^{*}} \cdot\left[\begin{array}{c}
\boldsymbol{u}_{k}^{1} \\
\vdots \\
\boldsymbol{u}_{k}^{n}
\end{array}\right] \Delta \boldsymbol{x} .
$$

Consequently the dynamics of a simple gradient procedure with a factor $\alpha$ satisfying condition (17) is described by the system with a next structure (Fig. 4).
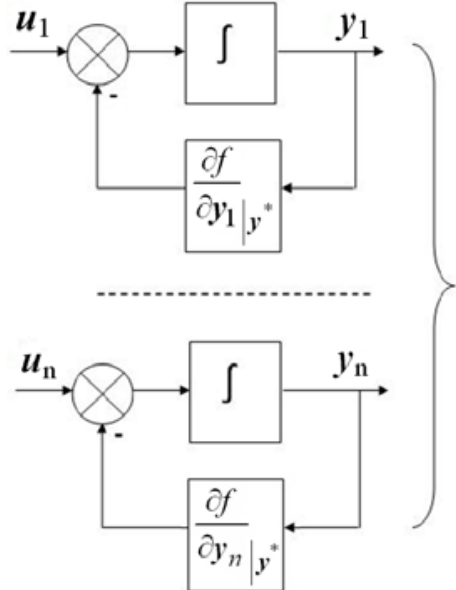

Figure 4 - Model for the dynamics of the gradient procedure

In this case, the sequence of transitions in the gradient procedure that determines the motion of the system is associated with transitions in the space of variables and the change of state - the value of the goal function.

Actually, the change of the value in the target function determines the transient process in the model (Fig. 5, 6):

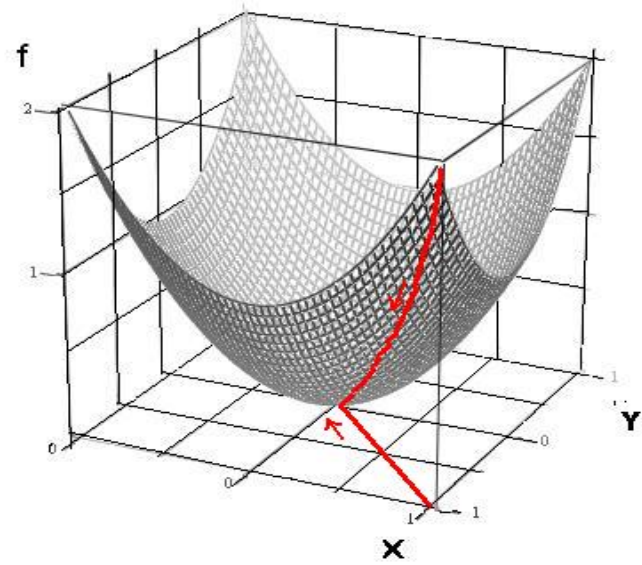

Figure 5 - The process of minimizing the function

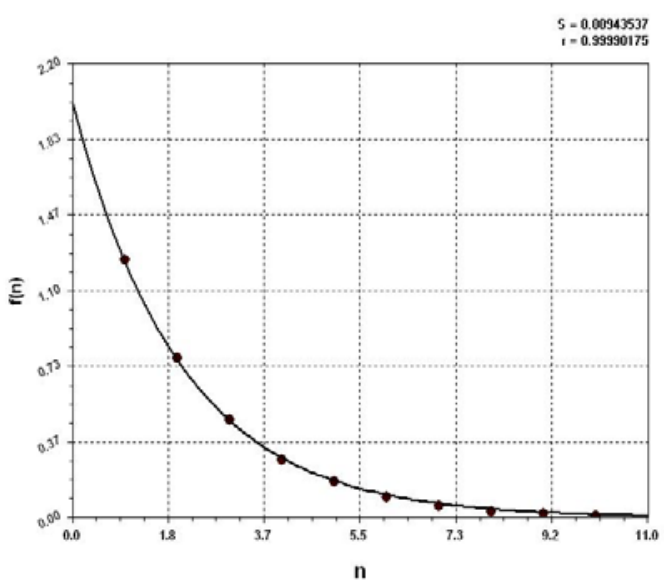

Figure 6 - The transient process of the dynamic model 
As it can be seen from Fig. 5, 6 the transient process in the dynamic system coincides with the process of changing the value of the objective function in the gradient procedure.

We can perform an analysis of the assumptions made using the standard quadratic goal function.

Thus, for the processes shown in Fig. 3, 4 the objective function $f(x, y)$ is chosen to be convex by the formula (20):

$$
f(x, y)=x^{2}+y^{2} .
$$

The gradient procedure was used with the formula (21):

$$
\left[\begin{array}{c}
\boldsymbol{y}_{k+1}^{1} \\
\vdots \\
\boldsymbol{y}_{k+1}^{n}
\end{array}\right]=\left[\begin{array}{c}
\boldsymbol{y}_{k}^{1} \\
\vdots \\
\boldsymbol{y}_{k}^{n}
\end{array}\right]+\left(\begin{array}{ccc}
\frac{\partial f}{\partial \boldsymbol{y}_{1}} & \cdots & 0 \\
\cdots & \cdots & \cdots \\
0 & \cdots & \frac{\partial f}{\partial \boldsymbol{y}_{n}}
\end{array}\right)_{\boldsymbol{y}^{*}} \cdot \Delta \mathbf{x} .
$$

For the chosen target function (20) and constant step $\Delta \boldsymbol{x}$ we obtain the formula (22):

$$
\left.\begin{array}{l}
\boldsymbol{x}_{k+1}=\boldsymbol{x}_{k}-2 \boldsymbol{x}_{k} \cdot \Delta \boldsymbol{x} \\
\boldsymbol{y}_{k+1}=\boldsymbol{y}_{k}-2 \boldsymbol{y}_{k} \cdot \Delta \boldsymbol{y}
\end{array}\right\} \text {. }
$$

In this case it gives the model for the dynamics of the gradient procedure in the form of a discrete Runge-Kutta model of the first order for the autonomous motion of an object by the formula (23):

$$
\left.\begin{array}{l}
\frac{d \boldsymbol{x}}{d t}=-2 \boldsymbol{x} \\
\frac{d \boldsymbol{y}}{d t}=-2 \boldsymbol{y}
\end{array}\right\} .
$$

The solution of the disconnected system (23) gives a combination of exponentials by the formula (24):

$$
\left.\begin{array}{l}
\boldsymbol{x}(t)=1 \cdot e^{-2 t} \\
\boldsymbol{y}(t)=1 \cdot e^{-2 t}
\end{array}\right\}
$$

After substituting the coordinates in (20) we obtain the trajectory of the objective function by the formula (25):

$$
f(\boldsymbol{x}, \boldsymbol{y})=\boldsymbol{x}(t)^{2}+\boldsymbol{y}(t)^{2}=2 \cdot e^{-4 t} .
$$

Thus, taking into account the sufficient conditions of the optimum [10] around the optimum point the dynamics of the gradient procedure is described by the free motion of the linear dynamical system.

For the factor $\alpha$ containing the coordinate, we obtain a procedure with nonlinearity and, as a consequence, the transient process loses exponentiality.

Let's consider the procedure with the formula (26):

$$
\left.\begin{array}{l}
\boldsymbol{x}_{k+1}=\boldsymbol{x}_{k}-\frac{\partial f}{\left.\partial \boldsymbol{x}\right|_{\boldsymbol{x}_{k}}} \boldsymbol{x}_{k} \cdot \Delta \boldsymbol{x} \\
\boldsymbol{y}_{k+1}=\boldsymbol{y}_{k}-\frac{\partial f}{\partial \boldsymbol{y}_{\left.\right|_{k}}} \boldsymbol{y}_{k} \cdot \Delta \boldsymbol{y}
\end{array}\right\} .
$$

We obtain a transient process with the approximation of the transient process by the fractional function a) and the exponent function b) by the formula (27):

$$
\begin{aligned}
& \text { a) } x=i, \quad f(x)=\frac{2-0.02 x}{1+0.5 x+0.05 x^{2}} \\
& \text { b) } \quad x=i \quad f(x)=2 e^{-0.3 x}
\end{aligned}
$$

The graphs of the transient process are shown in Fig. 7, 8 .

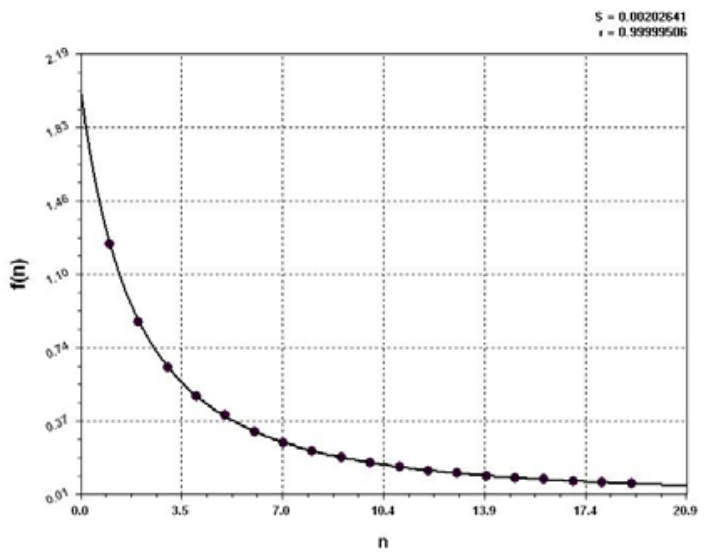

Figure 7 - Approximations of the transient process by the power function

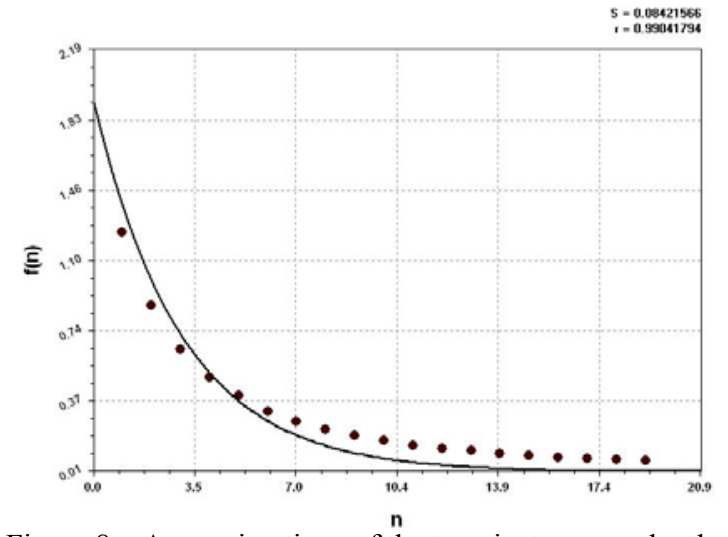

Figure 8 - Approximations of the transient process by the exponent function

As it can be seen from these graphs, the transient process is described by a fractional-rational function for the procedure (26).

An essential advantage of this approach is the ability to determine the required number of steps to achieve specified accuracy in determining the minimum value of the goal function. Indeed, it follows from (25) that for the initial value of the target function $f=f_{0}$ and the given value $f=f^{*}$ for a given $\lambda$ we obtain the formula (28):

$$
] i_{m}\left[=-\frac{1}{\lambda} \ln \frac{f^{*}}{f_{0}}\right.
$$

The obtained expression allows us to estimate the time of finding the optimal solution.

Thus, it is possible to estimate the time of "learning" which is essential in planning the learning process. 
The second essential point in the learning task is the concept of effective learning.

There are methods for evaluating learning outcomes, from simple assessments based on desirability scales to elaborate calculations, e.g., the ratio of the average score of trainees.

To have a true assessment, we use the following: suppose that the gross domestic product (GDP) depends on many factors, including the costs of education.

Then, having designated GDP as $W$ and education costs as $\varepsilon$, we can determine the efficiency of education as a component of the series taking into account other $\operatorname{costs} \chi$ by the formula (29):

$$
W=W_{0}+\left.\frac{d W}{d \varepsilon}\right|_{\chi=c o n s t} \Delta \varepsilon+\ldots+R .
$$

Thus, we have the current value of GDP and the GDP derivative for educational expenditures, while other expenditures are constant, in fact, the assessment of the effectiveness of education is determined by the sensitivity of GDP to the costs of education by the formula (30):

$$
\eta=\frac{d W}{d \varepsilon} \mid \chi=c o n s t
$$

\section{EXPERIMENTS}

To carry out experimental studies, computer software was created, supplementing existing standard software, which allowed to implement the developed models of training procedures in practice and perform their expert evaluation.

The proposed software was applied consistently to all developed key models of training procedures.

The output test data for each key model of training procedures contained 100 data sets, as well as the values of the allowable number of steps and errors.

On the basis of the output test data, validity estimates of the models of the training procedures were obtained.

It was found that the real and reference values of the validity estimates for the developed models of dynamic training procedures coincide, taking into account the permissible errors.

\section{RESULTS}

After having completed the studies the following results were obtained.

1. The notion of "information flow" is justified as the sequence of messages carrying information, for building models of interactions in information systems.

2. The important property of the information flow is determined - the direction from the source to the receiver.

3. There are two possible options for information interaction of objects - the transfer and compensation of information.

4. The use of the principle of optimality for information learning processes is proposed.

5. It is shown that the dynamics of learning processes is determined by the characteristics of the used optimization procedure.

(C) Khodakov V. Ye., Sokolov A. Ye., Veselovskaya G. V., 2018 DOI 10.15588/1607-3274-2018-4-5
6. The gradient procedure for finding the extremum of the goal function is described by the autonomous motion of the dynamic system.

7. For a strictly convex goal function, according to sufficient optimality conditions, the optimization procedure is described by the dynamics of the autonomous motion of a stationary linear disconnected dynamic object.

8. The choice of the multiplier for the gradient significantly affects the dynamics of the process, and for a strictly convex target function the factor is equal to the increment vector.

9. The use of a dynamic model determines the number of steps required to achieve the given accuracy.

The created models received software implementation and were investigated in practice when solving the tasks of modeling the dynamics of training procedures in the teaching process of the Information Technologies Department of Kherson National Technical University.

Let's analyze the obtained demonstrative experimental data presented in Table 1, where the following types of trainees target categories are considered, depending on their academic performance: category A - "very strong"; category B - "strong"; category C - "medium"; category D - "weak"; category E - "very weak"; category F "unsuccessful (receiving positive assessments only after retake)".

As results, in Table 1 are presented: increment 1 increment of saving time for passing training procedures by trainees; increment 2 - increment in the amount of learning by the trainee learning information; increment 3 - improving the quality of learners' learning information; increment 4 - increment of the integral indicator of the training procedures effectiveness (in scoring points).

Table 1 - Indicative fragment of the summary experimental data on the results of the research and development performed

\begin{tabular}{|c|c|c|c|c|c|c|c|}
\hline \multirow{2}{*}{ № } & \multirow{2}{*}{$\begin{array}{c}\text { Type } \\
\text { of target } \\
\text { trainees } \\
\text { category }\end{array}$} & \multirow{2}{*}{ 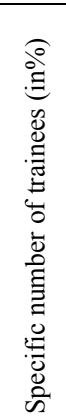 } & \multirow{2}{*}{ 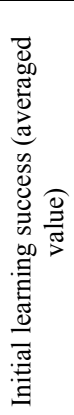 } & \multicolumn{4}{|c|}{$\begin{array}{c}\text { Trends } \\
\text { in the success } \\
\text { of training } \\
\text { after applying } \\
\text { the proposed modeling } \\
\text { methods: }\end{array}$} \\
\hline & & & & 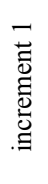 & 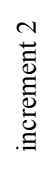 & 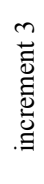 & 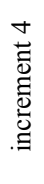 \\
\hline 1 & Category A & 10 & 92 & 3 & 5 & 4 & 4 \\
\hline 2 & Category B & 20 & 86 & 4 & 6 & 5 & 5 \\
\hline 3 & Category $\mathrm{C}$ & 20 & 78 & 6 & 8 & 7 & 7 \\
\hline 4 & Category D & 20 & 69 & 11 & 11 & 8 & 10 \\
\hline 5 & Category E & 20 & 62 & 16 & 14 & 12 & 14 \\
\hline 6 & Category $\mathrm{F}$ & 10 & 40 & 20 & 16 & 24 & 20 \\
\hline & $\begin{array}{l}\text { Average } \\
\text { for all } \\
\text { categories }\end{array}$ & 16,6 & 83.5 & 10 & 10 & 10 & 10 \\
\hline
\end{tabular}
(with a sample size of 100) 
As can be seen from Table 1, the tendencies of the training success after applying the proposed modeling methods progress in a positive direction for all trainees target categories, while the improvement of the learning success is most pronounced for the more "weak" trainees.

\section{DISCUSSION}

It is important to note that the modeling methods proposed by the authors and the corresponding mathematical apparatus on the basis of information theory should be considered as complementary to existing ones, which we combine into an integral system for optimization modeling methodology of the activities procedures dynamics related to educational processes and training, in particular.

Questions on optimization modeling for the activity procedures dynamics in educational processes were considered by a number of other authors from the point of view of separately singled out aspects, such as: didactic and psychological-pedagogical, connected with the processes for feeding portions of teaching material and controlling the results of their assimilation; cognitivecommunicative, using modern network computer technologies; socio-economic, etc.

Let's characterize some of the most revealing works that can be classified as research on optimization of activity procedures in the educational sphere, taking into account the dynamics factor.

The paper [15] raises the questions on dynamic modeling for the controlled process of competences acquisition by trainees on the basis of the cognitive modeling methodology, based on a valid assessment for the level of formation in the trainees competence.

In [16], carried out research and development in the field of mathematical modeling on professional orientation and knowledge control, taking into account the dynamics factor, based on the mathematical apparatus of deductive logical conclusion, fuzzy estimation methods, boundary-value problems for second-order differential equations such as Kolmogorov equations, probability theory, self-organization theory.

A complex of economic and mathematical models for mapping the demand dynamics on higher education institutions services based on logistic approaches, forecasting models, closed-loop control methodology, nonlinear dynamic modeling using iterative equations, reflexive control modeling using graph theory, is described in [17].

The peculiarity and uniqueness of this work is as follows.

The basis of the methods and mathematical models proposed by the authors is the concept of a comprehensive study of the learning process as an integral, purposeful dynamic information process that encompasses the entire spectrum for classes of interconnected activity procedures that form the given level of trainees knowledge, skills and habits as their "information richness" level.
Proceeding from the revealed specific features of the subject area corresponding to the chosen conceptual approach, the authors step-by-step selected and formed the mathematical modeling apparatus.

Thus, there is a situation where:

- in the works of several authors, the set of local aspects and aspects tied to individual parties of the education sector, for the general problem on modeling educational processes and procedures, taking into account the dynamics factor, is studied;

- a similar consideration for certain partial criteria at the moment does not give a sufficiently complete approximation to the general model;

- the methods and models proposed by the authors supplement the existing approaches, contributing a certain significant part, and, accordingly, contribute to a significant increase in the effectiveness of the educational process in accordance with Table 1, the integral indicator of the learning processes effectiveness increases by $10 \%$.

As evidenced by the results of the experiments, with the increase in the dynamics of the training procedures within the established (allowed) situations of their implementation, the validity estimates of the proposed models remain within the established interval reference values (taking into account the permissible errors).

Along with the above, non-standard (force majeure) situations of learning processes and their dynamics require additional research and refinement of models.

\section{CONCLUSIONS}

The carried out experimental researches have allowed to confirm practically operability of the created mathematical apparatus and to consider it expedient for application with the purpose of increase of efficiency of modeling and realization of procedures of training.

The scientific novelty of the results is that for the first time the method in optimization modeling of the activitybased learning procedures dynamics on the basis of the information theory is proposed, which is based on the conceptual model of the learning process as an integral, purposeful dynamic information process represented by a full-scale complex of interrelated activity information procedures that form, on the whole, at a given level, the information base of knowledge, abilities and skills of trainees. The method makes it possible to obtain optimal, in accordance with a given accuracy, models for the behavior over time of gradient training procedures; in this case, it is possible to determine the number of steps necessary to achieve a given accuracy in obtaining the minimum for the objective function, as well as the time to find the optimal solution. This makes it possible: to shorten the time for students to undergo training procedures; increase the volume and improve the quality of assimilation by the trainee learning information. In turn, this allows students to receive higher scores.

Within the framework of the proposed method, basic principles and main mathematical models of dynamic training procedures are defined. 
The practical significance of obtained results is that they allow to increase the productivity of training procedures.

Prospects for further research are seen in the coverage of more types of dynamic training procedures, optimizing approaches to their software implementations, and increasing the scale of their coverage with confirmatory experiments.

\section{ACKNOWLEDGEMENTS}

The work is supported by the scientific research project of Kherson National Technical University "Development of software for analysis of the organizational structure of the enterprise" (state registration number PK0116U005663) and by the international project 561728-EPP-1-2015-1-ES-EPPKA2CBHE-JP “GameHub: University-enterprises cooperation in game industry in Ukraine" of International program Erasmus + KA2 - Cooperation for innovation and the exchange of good practices - Capacity Building in the field of Higher Education.

\section{REFERENCES}

1. Mitrofanov K. G., Zaytseva O. V. Primeneniya innovatsionnyih kompyuternyih tehnologiy $\mathrm{v}$ sfere obrazovaniya: osnovnyie aspektyi i tendentsii, Vestnik TGPU, 2009, Vyip. 10 (88), pp. 64-68.

2. Alsied S. M., Pathan M. M. The use of computer technology in EFL classroom: Advantages and implications, International Journal of English Language and Translation Studies, 2013, Vol. 1, Issue 1, April-June, pp. 61-71.

3. Blurton C. New Directions of ICT - Use in Education. United National Education Science and Culture Organization (UNESCO), 1999.
4. Viner N. Per. s angl. I. V. Soloveva i G. N. Povarova; Pod red G. N. Povarova. Kibernetika, ili Upravlenie i svyaz v zhivotnom i mashine. 2-e izdanie. Moscow, Nauka, Glavnaya redaktsiya izdaniy dlya zarubezhnyih stran, 1983, $344 \mathrm{p}$.

5. Atanov G. A. Deyatelnostnyiy podhod v obuchenii. Donetsk, EAI press, 2001, $160 \mathrm{p}$.

6. Chaplin J. P. Dictionary of Psychology. N.J., 1985, 528 p.

7. Kolmogorov A. N. Teoriya informatsii i teoriya algoritmov. Moscow, Nauka, 1987, 304 p.

8. Znanie [Elektronnyiy resurs]. Rezhim dostupa: dic.academic.ru.

9. Esipov B. A. Metodyi optimizatsii i issledovaniya operatsiy Uchebnoe posobie. Samara, Izd-vo. Samar. aerokosm. un-ta, 2007, $180 \mathrm{p}$.

10. Chernorutskiy I. G. Metodyi optimizatsii v teorii upravleniya: Uchebnoe posobie. SPB, Piter, 2004, 256 p.

11. LarIonov Yu. I. DosIIzhdennya operatsIy: Navchalniy posyibnik. Harkiv, V.D. «INZhEK», 2005, 288 p

12. Panteleev A. V., Letova T. A. Metodyi optimizatsii v primerah zadachah: Uchebnoe posobie. 2-e izdanie, ispravl. A. V. Panteleev. Moscow, Vyissh. shkola, 2005, 544 p.

13. Kim D. P. Teoriya avtomaticheskogo upravleniya. Tom 1 Lineynyie sistemyi. Moscow, Fizmatlit, 2003, 288 p.

14. Vasilev F. P. Chislennyie metodyi resheniya ekstremalnyih zadach: Uchebnoe posobie dlya VUZov. - 2-e izdanie, pererab. i dop. Moscow, Nauka, G1. red. fiz.-mat. lit., 1988, 552 s.

15. Moskaleva S. S. Programmnaya podderzhka ekspertnoy otsenk kriteriev dlya postroeniya kognitivnoy modeli, Obrazovatelnyie resursyi i tehnologii, 2014, pp. 97-101.

16. Samoylo I. V. Matematicheskie modeli i algoritmyi professionalnoy orientatsii i upravleniya znaniyami: avtoref. dis. na soiskanie uchen. stepeni kand. tehn. nauk : spets. 05.13.10 "Upravlenie v sotsialnyih i ekonomicheskih sistemah". Moscow, 2010, 25 p.

17. Oharenko T. Yu. Modeliuvannia dynamiky popytu na posluhy vyshchykh navchalnykh zakladiv : avtoref. dys. na zdobuttia nauk. stupenia kand. ekon. nauk : spets. 08.00.11 "Matematychni metody, modeli ta informatsiini tekhnolohii v ekonomitsi." Zaporizhzhia, 2011, 23 p.

Received 23.05.2018 Accepted 18.06.2018

УДК 510.6

\section{МОДЕ ЛІ ПРОЦЕДУР НАВЧАННЯ}

Ходаков В. С. - д-р техн. наук, професор, завідувач кафедри інформаційних технологій Херсонського національного технічного університету, Херсон, Україна.

Соколов А. С. - канд. техн. наук, доцент, доцент кафедри інформаційних технологій Херсонського національного технічного університету, Херсон, Україна.

Веселовська Г. В. - канд. техн. наук, доцент, доцент кафедри інформаційних технологій Херсонського національного технічного університету, Херсон, Україна.

Актуальність. Розглянуто задачу обгрунтування методів побудови моделей оптимізаційних процедур, як динамічних об'єктів, із урахуванням особливостей процедур навчання. Об'єктом дослідження є моделі динаміки процедур навчання. Мета роботи розв'язування задач формалізації процедур навчання, розробки методів побудови математичних моделей процесів навчання, процесів пошуку оптимуму задач навчання, для оцінки динамічних процедур навчання.

Метод. Процес навчання - це сукупність послідовних і взаємопов'язаних дій того, хто навчає, та тих, кого навчають, спрямованих на забезпечення свідомого та міцного засвоєння знань, умінь, навичок. У результаті систематичного аналізу, визначені основні, базові закономірності процедур навчання. Обгрунтоване поняття «інформаційний потік», як послідовність повідомлень, що несуть інформацію, для побудови моделей взаємодій в інформаційних системах. Визначено важливу властивість інформаційного потоку - напрямок від джерела до приймача. Виділені два можливих варіанти інформаційної взаємодії об'єктів передача та компенсація інформації. Запропоноване використання принципу оптимальності для інформаційних процесів навчання. Показано, що динаміка процесів навчання визначається характеристиками використовуваної оптимізаційної процедури. Градієнтна процедура пошуку екстремуму функції мети описується автономним рухом динамічної системи. Для строго опуклої функції мети, згідно достатніх умов оптимальності, процедура оптимізації описується динамікою автономного руху стаціонарного лінійного незв'язаного динамічного об'єкту. Вибір множника для градієнту істотно впливає на динаміку процесу, та для строго опуклої функції мети множник дорівнює вектору збільшень. Використання динамічної моделі визначає необхідну кількість кроків досягнення заданої точності.

Результати. Створені моделі отримали програмну реалізацію та були досліджені на практиці при розв'язуванні задач моделювання динаміки процедур навчання в навчальному процесі кафедри інформаційних технологій Херсонського національного технічного університету.

Висновки. Виконані експериментальні дослідження дозволили практично підтвердити працездатність створеного математичного апарату та вважати його доцільним для застосування з метою підвищення ефективності моделювання та реалізації процедур навчання. Подальші перспективи проведених досліджень бачаться в охопленні більшої кількості видів динамічних 
процедур навчання, оптимізації підходів до їхніх програмних реалізацій, збільшенню масштабності їхнього охоплення підтверджувальними експериментами.

КЛЮЧОВІ СЛОВА: навчання, формалізація процедур навчання, вчитель, той, хто навчається, інформаційний потік, оптимізаційні процедури.

УДК 510.6

\section{МОДЕЛИ ПРОЦЕДУР ОБУЧЕНИЯ}

Ходаков В. Е. - д-р техн. наук, профессор, заведующий кафедрой информационных технологий Херсонского национального технического университета, Херсон, Украина.

Соколов А. Е. - канд. техн. наук, доцент, доцент кафедры информационных технологий Херсонского национального технического университета, Херсон, Украина.

Веселовская Г. В. - канд. техн. наук, доцент, доцент кафедры информационных технологий Херсонского национального технического университета, Херсон, Украина.

Актуальность. Рассмотрена задача обоснования методов построения моделей оптимизационных процедур, как динамических объектов, с учетом особенностей процедур обучения. Объектом исследования являлись модели динамики процедур обучения. Цель работы - решение задач формализации процедур обучения, разработки методов построения математических моделей процессов обучения, процессов поиска оптимума задач обучения, для оценки динамических процедур обучения.

Метод. Процесс обучения - это совокупность последовательных и взаимосвязанных действий обучающего и обучаемых, направленных на обеспечение сознательного и прочного усвоения знаний, умений, навыков. В результате систематического анализа, определены основные, базовые закономерности процедур обучения. Обосновано понятие «информационный поток», как последовательность сообщений, несущих информацию, для построения моделей взаимодействий в информационных системах. Определено важное свойство информационного потока - направление от источника к приемнику. Выделены два возможных варианта информационного взаимодействия объектов - передача и компенсация информации. Предложено использование принципа оптимальности для информационных процессов обучения. Показано, что динамика процессов обучения определяется характеристиками используемой оптимизационной процедуры. Градиентная процедура поиска экстремума функции цели описывается автономным движением динамической системы. Для строго выпуклой функции цели, согласно достаточным условиям оптимальности, процедура оптимизации описывается динамикой автономного движения стационарного линейного несвязанного динамического объекта. Выбор множителя для градиента существенно влияет на динамику процесса, и для строго выпуклой функции цели множитель равен вектору приращений. Использование динамической модели определяет необходимое число шагов достижения заданной точности.

Результаты. Созданные модели получили программную реализацию и были исследованы на практике при решении задач моделирования динамики процедур обучения в учебном процессе кафедры информационных технологий Херсонского национального технического университета.

Выводы. Выполненные экспериментальные исследования позволили практически подтвердить работоспособность созданного математического аппарата и считать его целесообразным для применения с целью повышения эффективности моделирования и реализации процедур обучения. Дальнейшие перспективы проведенных исследований видятся в охвате большего количества видов динамических процедур обучения, оптимизации подходов к их программным реализациям, увеличению масштабности их охвата подтверждающими экспериментами.

КЛЮЧЕВЫЕ СЛОВА: обучение, формализация процедур обучения, учитель, учащийся, информационный поток, оптимизационные процедуры.

\section{ЛІТЕРАТУРА/ЛИТЕРАТУРА}

1. Митрофанов К. Г. Применения инновационных компьютерных технологий в сфере образования: основные аспекты и тенденции / К. Г. Митрофанов, О. В. Зайцева // Вестник ТГПУ. - 2009. - Вып. 10 (88). - С. 64-68.

2. Alsied S. M. The use of computer technology in EFL classroom Advantages and implications / S. M. Alsied, M. M. Pathan // International Journal of English Language and Translation Studies. - 2013. - Vol. 1, Issue 1, April-June. - P. 61-71.

3. Blurton C. New Directions of ICT - Use in Education / C. Blurton. - United National Education Science and Culture Organization (UNESCO), 1999.

4. Винер Н. Кибернетика, или Управление и связь в животном и машине. - 2-е издание / Н. Винер; Пер. с англ. И. В. Соловьева и Г. Н. Поварова; Под ред. Г.Н. Поварова. - М. : Наука Главная редакция изданий для зарубежных стран, 1983. - 344 с.

5. Атанов Г. А. Деятельностный подход в обучении Г. А. Атанов. - Донецк : ЕАИ пресс, 2001. - 160 с.

6. Chaplin J. P. Dictionary of Psychology / J. P. Chaplin. - N.J., 1985. $-528 \mathrm{p}$

7. Колмогоров А. Н. Теория информации и теория алгоритмов А. Н. Колмогоров. - М. : Наука, 1987. - 304 с.

8. Знание [Электронный ресурс]. - Режим доступа: dic.academic.ru.

9. Есипов Б. А. Методы оптимизации и исследования операций: Учебное пособие / Б. А. Есипов - Самара : Изд-во. Самар. аэрокосм. ун-та, 2007. - $180 \mathrm{c}$
10. Черноруцкий И. Г. Методы оптимизации в теории управления : учебн. пособие / И. Г. Черноруцкий. - СПБ : Питер, 2004. $256 \mathrm{c}$.

11. Ларіонов Ю. І. Досліждення операцій : навч. пос. / Ю. І. Ларіонов. - Харків : В. Д. «ІНЖЕК», 2005. - 288 с.

12. Пантелеев А. В. Методы оптимизации в примерах и задачах учебн. пос. - 2-е издание, исправл. / А. В. Пантелеев, Т. А. Летова. - М. : Высш. школа, 2005. - 544 с.

13. Ким Д. П. Теория автоматического управления. Том 1. Линейные системы / Д. П. Ким. - М. : Физматлит, 2003. - 288 с.

14. Васильев Ф. П. Численные методы решения экстремальных задач : учебн. пособие для ВУЗов. - 2-е издание, перераб. и доп. / Ф. П. Васильев. - М. : Наука, Гл. ред. физ.-мат. лит., 1988. $-552 \mathrm{c}$

15. Москалева С. С. Программная поддержка экспертной оценки критериев для построения когнитивной модели / С. С. Москалева // Образовательные ресурсы и технологии. 2014. - C. 97-101.

16. Самойло И. В. Математические модели и алгоритмы профессиональной ориентации и управления знаниями: автореф. дис. на соискание учен. степени канд. техн. наук : спец. 05.13.10 «Управление в социальных и экономических системах» / И. В. Самойло. - М. :, 2010. - 25 с.

17. Огаренко Т. Ю. Моделювання динаміки попиту на послуги вищих навчальних закладів : автореф. дис. на здобуття наук. ступеня канд. екон. наук : спец. 08.00.11 «Математичні методи, моделі та інформаційні технології в економіці» / Т. Ю. Огаренко. - Запоріжжя, 2011. - 23 с. 